\title{
PCB BIODEGRATION USING BACTERIA ISOLATED FROM LANDFILL LEACHATE
}

Noor Faizul Hadry Nordin1,2, Siti Nur Nadiah Binti Mohd Idris1, Mohd Nazri Mohd Nawi1, Akbar John3, Ahmed Jalal Khan Chowdhury3*

${ }^{1}$ Department of Biotechnology Engineering, Kuliyyah of Engineering, International Islamic University Malaysia (IIUM), Jalan Gombak, 53100 Kuala Lumpur, Malaysia

${ }^{2}$ International Institute for Halal Research and Training (INHART), International Islamic University Malaysia (IIUM), Jalan Gombak, 53100 Kuala Lumpur, Malaysia

*Kulliyyah of Science, International Islamic University Malaysia, Jalan Sultan Ahmad Shah, Bandar Indera Mahkota, Kuantan, Pahang, Malaysia

Corresponding author email: jkchowdhury@iium.edu.my

This is an open access article distributed under the Creative Commons Attribution License, which permits unrestricted use, distribution, and reproduction in any medium, provided the original work is properly cited

\section{ARTICLE DETAILS}

\section{Article History:}

Received 3 July 2017

Accepted 3 October 2017

Available online 2 November 2017

Keywords:

PCB, Biodegradation, Leachate, Optimization, GC-MS, Solid phase extraction.

\section{ABSTRACT}

Polychlorinated biphenyls, PCBs are toxic, persistent organic pollutants (POP) which are harmful to human and environment due to their lipophilic characteristic and not easily degraded in the environment. Biodegradation is one of the alternative ways to reduce PCBs contamination. This study intended to isolate bacteria from landfill leachate using enrichment culture technique and optimize the growth condition of selected isolates for degradation of PCBs. PCB biodegradation efficiency by selected bacterial isolates was also determined using GC-MS. Three potential PCBs degraders were isolated from the samples of landfill leachate through enrichment culture technique, which utilised PCBs as sole carbon and energy sources but only isolate T12B shown significant effect on the degradation. Three different growth parameters were optimized involving the temperature, $\mathrm{pH}$, and PCBs concentration. Central composite design (CCD) from Design Expert Software was used to design the experiment. The optimal growth condition of temperature at $37^{\circ} \mathrm{C}$ with $10 \mathrm{ppm}$ of PCB concentrations and $\mathrm{pH} 8$ for the culture medium was achieved using Response Surface Methodology (RSM) analysis. Based on GC-MS analysis, the reduction of PCBs concentration indicates that they were utilized by isolates T12B as sole of carbon and energy sources. This may suggest that bacteria in landfill leachate play an important role in biodegradation process as well as more effective and economical.

\section{INTRODUCTION}

Polychlorinated biphenyls (PCBs) are highly toxic pollutants and persistent chemical which have been spread over into the environment [1]. PCBs can be found in several products such as electrical appliances, ink and paint, surface coating and adhesives. The commercial PCB mixtures are Aroclor which was manufactured by Monsanto Chemical Company in the United States from 1930 - 1970. There are 209 different congeners that can be placed in particular number and position of the chlorines. Mostly, PCB congeners consist of five to seven chlorine atoms per molecules from PCB configuration [2].

Basically, the PCBs contaminants are continued to exist up until today [3]. This is because PCBs are strongly resistant to degradation due to their chemical stability to extreme temperature and pressure. PCBs pollutant accumulates in the water reservoirs vary significantly with their concentration which causes problem to the water ecosystem. It will carry the pollutant to plants and animal through water streams such as groundwater, lakes, and rivers [4]. Their hydrophobic characteristics give aptitude to PCBs to adsorb to the organic matter of soil and sediment [5]. Moreover, PCBs give an adverse effect on people, flora and fauna comprise of neurotoxicity, immunotoxicity, mutagenicity and carcinogenicity [6]. Due to PCBs persistent to soil and sediments, there are several techniques in order to degrade PCBs. It can be categorised to physical treatment, chemical treatment, and biological treatment. For instance, PCBs degradation by using incinerator or pyrolysis high temperature are mostly been proposed commercially. However, this technique is costly and likely produce undesirable by-product such as polychlorinated dibenzofurans (PCDFs) because of partial combustion [7]. Therefore, biodegradation have been proposed to upgrade the physical and chemical treatment for PCB degradation in environment [4].

\section{EXPERIMENTAL METHOD}

\subsection{Leachate sampling}

Leachate samples were collected from Tanjung 12, Kuala Langat, Selangor.

The sample was taken from the sanitary landfill in Selangor.

\subsection{M9 minimal media}

M9 minimal media is a culture medium that contains minimal necessities for growth of microorganism. It contains only a mineral salts, and water. The carbon sources are supplemented when necessary. $200 \mathrm{ml}$ of 5x M9 salt media, $2 \mathrm{ml}$ of $1 \mathrm{M} \mathrm{MgSO}_{4}$, and $1 \mathrm{M} \mathrm{CaCl}_{2}$ were mixed until it dissolves in $1000 \mathrm{ml}$ of distilled water. M9 minimal media was autoclaved for 15 minutes at $121^{\circ} \mathrm{C}$ for sterilization.

\subsection{Isolation of PCB degraders}

Isolation of potential PCB degraders was performed by spreading $200 \mu \mathrm{l}$ landfill leachate on M9 agar supplemented with PCB 52 (Sigma Aldrich) as carbon sources. The plates were incubated at $30^{\circ} \mathrm{C}$ for 48 hours. Subsequently, dilution streaking technique was used to obtain pure bacterial isolates.

\subsection{Selection of bacterial candidate}

The three isolated bacteria which are isolate $\mathrm{T} 12 \mathrm{~A}, \mathrm{~T} 12 \mathrm{~B}$, and $\mathrm{T} 12 \mathrm{C}$ were grown in $150 \mathrm{ml}$ of LB broth in $250 \mathrm{ml}$ Erlenmeyer flask and were incubated in rotary shaker with $200 \mathrm{rpm}$ overnight in $30^{\circ} \mathrm{C}$. The sample was centrifuged at $5000 \mathrm{rpm}$ for 10 minutes. The supernatant were removed and the pellet or bacteria cell were washed twice with M9 minimal media. The washed cells were transferred into $250 \mathrm{ml}$ Erlenmeyer flask with $150 \mathrm{ml}$ of M9 minimal media containing $10 \mathrm{ppm}$ of PCB 52 as sole carbon sources accordingly. The initial concentration of M9 for selected PCB degraders were adjusted to 0.3 of $\mathrm{OD}_{600}$. The three isolated bacteria cultures were incubated at $30^{\circ} \mathrm{C}$ with the rotation of 200 rpm. The three selected bacteria were pre-optimized in M9 minimal media with supplemented $10 \mathrm{ppm}$ of PCBs. The bacterial growth was measured after 48 hours of incubation period. 


\subsection{Optimization of Growth Parameter}

The central composite design in Design Expert 6.0 shows 17 runs of the experiment were conducted in order to find the optimum temperature, $\mathrm{pH}$, and concentration of PCBs. The temperature, $\mathrm{pH}$, and PCBs concentration were varied according to the Table 1 . Isolate $\mathrm{T} 12 \mathrm{~B}$ were chosen for the optimization due to higher growth reading compared to isolate T12A and T12C. Isolate T12B was prepared in $30 \mathrm{ml}$ of $\mathrm{M} 9$ minimal medium supplemented with different concentration of PCB 52 in the $50 \mathrm{ml}$ Falcon tube. The results were analysed using Response Surface Methodology (RSM).

Table 1: Parameters for optimization

\begin{tabular}{llll}
\hline Parameter & Low & Medium & High \\
\hline Temperature $\left({ }^{\circ} \mathrm{C}\right)$ & 23 & 30 & 37 \\
$\mathrm{pH}$ & 5 & 7 & 9 \\
Concentration of PCBs (ppm) & 5 & 10 & 15 \\
\hline
\end{tabular}

\subsection{Biodegradation studies using optimize growth condition}

The optimized conditions for T12B growth were used in order to determine the degradation efficiency. Isolate $\mathrm{T} 12 \mathrm{~B}$ were cultured in 100 $\mathrm{ml}$ of M9 minimal media supplemented with $10 \mathrm{ppm}$ PCBs concentration as sole carbon sources in $250 \mathrm{ml}$ Erlenmeyer flask. The absorbance of the suspension was measured in different range of hours $(0,6,12,24,48$ and 72 hours) with $\mathrm{OD}_{600}$. Each interval hours, $6 \mathrm{ml}$ from the samples were taken for the solid phase extraction method.

\subsection{Extraction of PCB}

The extraction of PCB from culture media was conducted using solid phase extraction method with SPE ENVI-18 column (Supelco). SPE ENVI-18 was conditioned using $4 \mathrm{~mL}$ of Acetonitrile followed by $4 \mathrm{~mL}$ of distilled water with a flow rate of $20 \mathrm{~mL} / \mathrm{min}$. Then, the sample was added into the column, the flow rate was adjusted to $10 \mathrm{~mL} / \mathrm{min}$. Subsequently, the column was washed with $6 \mathrm{~mL}$ of distilled water twice before adding $2 \mathrm{~mL}$ of methanol to speed up the drying of the column. The column was left to dry for 1 hour under vacuum. After drying, the glass tube was placed in the vacuum chamber for sample collection. The sample retain within the silica of the SPE column was eluted using $6 \mathrm{~mL}$ of hexane. The sample was concentrated to $2 \mathrm{~mL}$ using gentle blow of nitrogen gas before analysed by GC-MS.

\subsection{Analysis of PCB by GC/MS}

The extraction of PCBs was performed using LLE involving acid-base clean-up and the extracted compounds were quantified using GC-MS using Column HP 5MS. The samples were analyzed using MSD ChemStation (Agilent Technologies, Inc).

\section{RESULTS AND DISCUSSION}

\subsection{Isolation of PCB degraders}

The culture of bacteria was successfully grown on M9 minimal agar supplemented with $10 \mathrm{ppm}$ PCB- 52 in 48 hours at $30^{\circ} \mathrm{C}$ from the leachate samples. Based on the observation, there are only three colonies (T12A, T12B and T12C) grown in the M9 minimal medium supplemented with 10 ppm PCB-52. Bacteria that grow on the minimal medium with PCB as the sole carbon source were isolated from the samples of leachate. Biphenyls acts as inducer and their presence in the PCB compound is used to induce the PCB degradation pathway. Isolate T12B was selected as a potential PCB degradation based on its highest growth in M9 supplemented with PCB.

\subsection{Optimization Growth Parameter}

Central composite design (CCD) based method of Response Surface Methodology (RSM) was used to study the maximum microbial growth as shown in Table 2. Initial screening was performed to evaluate the effects of $\mathrm{pH}$, temperature and PCB concentration. The most significant factors for microbial growth are PCB concentration and temperature. Trial 13 shows the highest growth of bacteria produced with OD reading of 0.291 with the cell number of $97 \times 10^{6} \mathrm{CFU} / \mathrm{ml}$ at temperature of $37^{\circ} \mathrm{C}$ and concentration of 5 ppm respectively. Meanwhile, trial run 8 shows the lowest growth of bacteria produced with OD reading of 0.111 with the cell number of 37 $\mathrm{x} 106 \mathrm{CFU} / \mathrm{ml}$ at temperature of $23^{\circ} \mathrm{C}$ and concentration of $5 \mathrm{ppm}$. The microbial growth shows the capability of the bacteria to utilize PCBs as their sole of carbon sources. The results observed from this study also indicated that the highest bacteria growth with 0.291 with the cell number of $97 \times 10^{6} \mathrm{CFU} / \mathrm{ml}$ was correspond to the highest temperature with $37^{\circ} \mathrm{C}$.

Table 2: Matrix of central composite design and the response growth of bacteria

\begin{tabular}{llllll}
\hline $\begin{array}{l}\text { Trial } \\
\text { Run }\end{array}$ & $\mathbf{p H}$ & $\begin{array}{l}\text { Temperature } \\
\left({ }^{\circ} \mathbf{C}\right)\end{array}$ & $\begin{array}{l}\text { PCB } \\
\text { Concenration } \\
(\mathbf{p p m})\end{array}$ & $\begin{array}{l}\text { Response } \\
\text { Growth } \\
(\mathbf{O D})\end{array}$ & $\begin{array}{l}\text { Predicted } \\
\text { Growth } \\
(\text { OD) }\end{array}$ \\
\hline 1 & 6 & 30 & 5 & 0.18 & 0.172 \\
2 & 8 & 23 & 15 & 0.132 & 0.120 \\
3 & 4 & 30 & 10 & 0.218 & 0.184 \\
4 & 6 & 30 & 10 & 0.17 & 0.190 \\
5 & 4 & 37 & 5 & 0.145 & 0.165 \\
6 & 8 & 30 & 10 & 0.261 & 0.257 \\
7 & 6 & 37 & 10 & 0.211 & 0.195 \\
8 & 8 & 23 & 5 & 0.111 & 0.124 \\
9 & 4 & 23 & 15 & 0.123 & 0.138 \\
10 & 4 & 23 & 5 & 0.131 & 0.118 \\
11 & 6 & 30 & 10 & 0.185 & 0.190 \\
12 & 6 & 30 & 15 & 0.175 & 0.168 \\
13 & 8 & 37 & 5 & 0.291 & 0.283 \\
14 & 4 & 37 & 15 & 0.17 & 0.163 \\
15 & 8 & 37 & 15 & 0.239 & 0.257 \\
16 & 6 & 23 & 10 & 0.103 & 0.103 \\
17 & 6 & 30 & 10 & 0.18 & 0.190 \\
\hline
\end{tabular}

Analysis of variance (ANOVA) from the response surface for quadratic mode was performed using Design- expert software. The statistical of $F$ value, lack of fit and the $\mathrm{R}^{2}$-value were determined to evaluate the model of results. The p-value specify the model the response are significant based on the value of prob $>\mathrm{F}$ which is less than 0.05 . Furthermore, the lack of fit with a probability value greater than 0.1 is desired which shows that the model design can be considered as satisfactory.

The determination of coefficient, R-squared value for microbial growth with 0.9439 shows that $94 \%$ of the experimental data has the significant of the model. The adjusted R-squared for microbial growth with 0.8718 are not close enough with predicted R-squared for microbial growth with 0.1524 indicated that a large block effect the model. The predicted Rsquared value data was dropped from an overfit model due to many terms in the model. The adequate precision measure the signal to noise ratio which a ratio with greater than 4 is desirable. The ratio of 12.274 indicates an adequate signal for predicted the microbial growth.

The model from Equation 1 indicated that the $\mathrm{pH}$, A of the medium had a significant effect on the growth of bacteria, $\mathrm{Y}$ where it had the largest coefficient followed by temperature, B and PCB concentration. The positive coefficients of $A B, A^{2}$ indicate the direct affect on the microbial growth meanwhile the negative coefficients of $\mathrm{C}, \mathrm{AC}, \mathrm{B}^{2}$ and $\mathrm{C}^{2}$ had an inverse effect o microbial growth. The predicted growth values calculated in Table 2 is based on the final equation in terms of coded factors.

Growth $=+0.19+0.025 \mathrm{~A}+0.046 \mathrm{~B}-1.700 \mathrm{E}-003 \mathrm{C}+0.028 \mathrm{AB}-6.000 \mathrm{E}-$ $003 \mathrm{AC}-5.250 \mathrm{E}-003 \mathrm{~B} \mathrm{C}+0.042 \mathrm{~A} 2-0.041 \mathrm{~B} 2-0.020 \mathrm{C} 2$ (Equation 1)

Where $\mathrm{A}$ is $\mathrm{pH}, \mathrm{B}$ is temperature and $\mathrm{C}$ is $\mathrm{PCB}$ concentration.

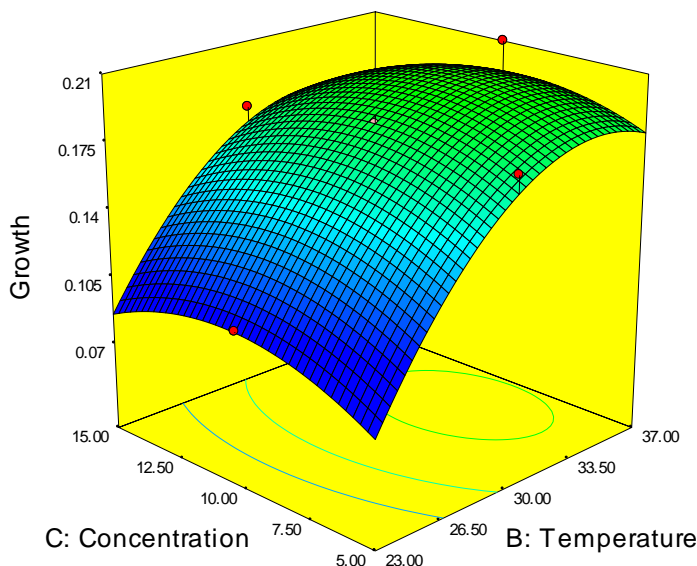

Figure 1: 3D graphics plot of microbial growth for response surface optimization

Figure 1 shows that the affect of temperature on the microbial growth. It can be seen that the highest growth of bacteria is at $37^{\circ} \mathrm{C}$ with $\mathrm{PCB}$ 
concentration of $10 \mathrm{ppm}$. The optimum responses were obtained at the centre point value with growth reading of 0.181 with number of viable cells of $60 \times 10^{6} \mathrm{CFU} / \mathrm{ml}$ at PCB concentration $(10 \mathrm{ppm})$. The result from indicated that PCB concentration and temperature has a great potential to degrade PCB with the highest growth reading. Based on a few assumptions, the growth is dependent on the biodegradation of PCBs where it indicated that the bacteria have been utilized the carbon sources from the degradation of PCBs since the M9 minimal medium do not contain any other carbon sources.

According to a study, bacteria in leachate can be categorized as mesophilic with the optimum temperature for growth condition from $37^{\circ} \mathrm{C}$ to $45^{\circ} \mathrm{C}$ [8]. The optimization of microbial growth is important in these studies in order to determine the utilization of PCB 52 as sole carbon sources for selected PCB degraders. Furthermore, current study has shown that bacteria growth in $\mathrm{pH}$ 6-8 which shows a significant result with the optimization result [9]. In further finding, $10 \mathrm{ppm}$ of PCB concentrations showed a significant effect in the microbial growth in which bacteria has utilized the PCB as sole carbon source [10].

\subsection{Analysis of PCB Degradation by GC-MS}

Isolate T12B was prepared in M9 minimal media supplemented with 10 ppm of PCB-52 for 72 hours at $\mathrm{pH} 7$ and incubation temperature of $30^{\circ} \mathrm{C}$. The samples of inoculation were collected at different intervals hours $(0$, $6,12,24,48,72$ hours). The growth reading of each interval were measured and compared based on the standard growth curve of isolate $\mathrm{T} 12 \mathrm{~B}$ depend on the number of colonies available in the suspension culture. Solid phase extraction method was performed using SPE ENVI-18 to extract PCB in aqueous form. Using GC-MS analysis, the decrease of PCBs concentration was measured. Figure 2 represent the biodegradation pattern of PCBs from isolate T12B. In general, in this study assumed that there is no PCB removal from photodegradation and volatilisation process as indicated in the ATSDR report [11].

The first 12 hours was a period of adaptation for the isolates T12B in the M9 minimal media. A group researcher indicates that the strongest adaptive response for bacteria is within 12 hours incubation period [12]. This finding shows that, most of the cells were died as shown in 2 since the isolates T12B were previously grown in LB media which contain high amount of carbon sources for them to utilise before being transferred to M9 minimal media. Based on the optimization method, $10 \mathrm{ppm}$ is the optimal PCB concentration for bacteria growth. Therefore, M9 minimal medium with the supplementation of $10 \mathrm{ppm}$ PCB concentration was used for the growth of bacteria in the degradation analysis.The concentration of PCB was decreased from $10 \mathrm{ppm}$ to $7.6 \mathrm{ppm}$ at the first 12 hours due to the availability of isolates T12B for adaptation period and utilised the PCBs as sole of carbon sources. After 24 hours, the population of isolates T12B double from the population number in 12 hours which are around $85 \times 10^{6} \mathrm{CFU} / \mathrm{ml}$. Decreasing of PCBs concentration from $7.46 \mathrm{ppm}$ to 5.42 $\mathrm{ppm}$ led to the increased of growth bacteria as shown in Figure 2. A slow growth of isolates T12B was identified after 48 hours. A group of scientist reported that carbon sources utilization becomes a limiting factor for a growth of bacteria [13]. The growth was completely inhibited after 72 hours in the reduction of PCBs concentration to $1.27 \mathrm{ppm}$ where it shows isolates T12B in the M9 media supplemented with $10 \mathrm{ppm}$ of PCBs has utilised almost the carbon sources supplied in the media. According to the graph, the remaining PCBs concentration after biodegradation was found around $15 \%$.

The growth rate of isolates T12B from 48 hours to 72 hours was decreased. During the growth, it indicates that the bacteria cannot sustain their cell's multiplication due to the limited carbon sources. Based on the PCBs concentration, $10 \mathrm{ppm}$ was not enough for the selected PCB degraders, isolates T12B to grow and utilise the carbon sources. In a research paper, demonstrated the supplementation of PCBs may affect the growth rates of microorganism.Three different concentration were used which are $0 \mathrm{ppm}, 10 \mathrm{ppm}$ and $50 \mathrm{ppm}$. The culturable microorganism shows a high population growth at $10 \mathrm{ppm}$ with $9.5 \times 10^{4} \mathrm{CFU} / \mathrm{ml}$ compared to $50 \mathrm{ppm}$ with $1.1 \times 10^{4} \mathrm{CFU} / \mathrm{ml}$ [14].The growth rate with 85 $\mathrm{x} 10^{6} \mathrm{CFU} / \mathrm{ml}$ shows evidence that bacteria can utilised the carbon sources within 24 hours. These findings suggest that the microbial population with the capability to utilise and degrade the PCBs was larger at the concentration of $10 \mathrm{ppm}$..

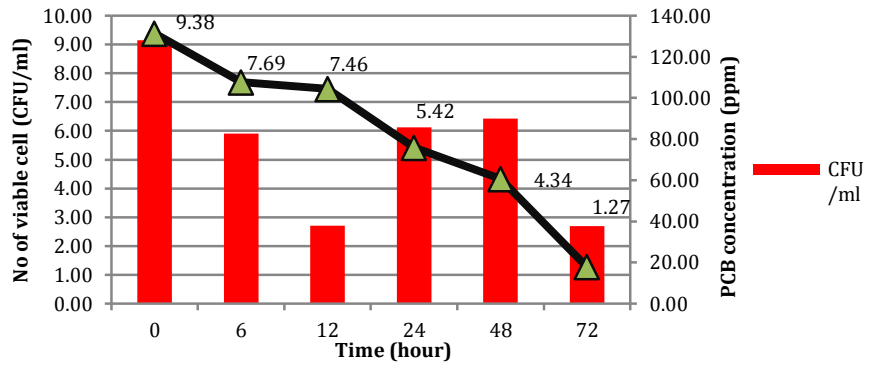

Figure 2: Correlation of removal of PCBs with growth of isolate T12B

The degradation study of polychlorinated biphenyls are relevant to environmental concern by studying the factor of optimum growth condition for bacteria and carbon source competition for bacterial growth rates. Selected PCB degraders can be isolated from landfill leachate. Despite previous studies indicates that the diversity of microorganism in the leachate with the dominant of bacteria are extremely high with more than 103 strains. Due to high chemical waste composition with different organic and inorganic substances, the microbial diversity in the leachate is a good medium for the biodegradation [15]. This work has explained a significant role of bacterial isolates from landfill leachate as potential PCB degraders for in situ biodegradation [14]

Isolate T12B shows ability on the degradation which depend on the optimal growth condition which $\mathrm{pH}$, PCBs concentration and temperature. This study can be improved by increasing the amount of PCBs concentration utilised by the bacteria and also the optimum incubation temperature for the bacteria. Previous study, indicated that B. Xenovorans strain $L B 400$ is the potential PCB degraders with the optimum condition of $30{ }^{\circ} \mathrm{C}$ [12]. However, in this studies, the optimum growth condition cannot be identified due to the range of temperature is between $23^{\circ} \mathrm{C}$ to $37^{\circ} \mathrm{C}$. This may suggest that isolate T12 B from landfill leachate may need a higher temperature which is more than $37{ }^{\circ} \mathrm{C}$ to get the optimum temperature for the degradation. Apart from that, based on the optimization method, this study demonstrated the significant model for bacteria growth rate as shown in Table 2. Moreover, the results give some clues about the effect of temperature on the degradation of PCBs by isolate T12B.

The finding of this study strongly suggest that bacterial isolate from landfill leachate are associated with the biodegradation of PCBs. The PCB degrading microorganism especially isolates T12B has been investigated as a potential degraders based on the utilization of carbon sources from PCBs. A studie stated that the certain trees species in the contaminated area contain PCB metabolizing bacteria attached in root zone are identified as a PCB degraders [16]. The report shows the degradation activities of the PCB degrading bacteria also may be found in the landfill for the long term degradation studies [17]. It indicated that the microbial species from the landfill leachate may support the biodegradation for future investigations. The observations are relied on the culture based measurement on the microbial numbers which likely detected only a small fraction of potential PCB degraders in the environment. The optimization and degradation methods have the potential to significantly improve the growth parameter for bacterial community and the activity of PCB degradation. Apart from that, the finding of this studies shows the selected PCB degraders can actively involved in PCB degradation at the site of contamination area such as landfill.

\section{ACKNOWLEDGEMENT}

This research was supported by IIUM and MOHE for funding this project through Research Initiative Grant Scheme and ERGS13-026-0059, respectively.

\section{REFERENCES}

[1] Donnelly, P. K., Hegde, R. S., and Fletcher, J. S. 1994. Growth of PCBdegrading bacteria on compounds from photosynthetic plants. Chemosphere, 28 (5), 981-988.

[2] McFarland, V. A., and Clarke, J. U. 1989. Environmental occurrence, abundance, and potential toxicity of polychlorinated biphenyl congeners: considerations for a congener-specific analysis. Environmental Health Perspectives, 81, 225.

[3] Learn about Polychlorinated Biphenyls (PCBs) | Polychlorinated Biphenyls (PCBs) | US EPA. (2017). Epa.gov. Retrieved 20 May 2017, from https://www.epa.gov/pcbs/learn-about-polychlorinated-biphenyls-pcbs 
[4] Grabowska, I. 2010. Polychlorinated biphenyls (PCBs) in Poland: occurrence, determination and degradation. Polish Journal of Environmental Studies, 19 (1), 7-13.

[5] Sylvestre, M., Massé, R., Ayotte, C., Messier, F., and Fauteux, J. 1985. Total biodegradation of 4-chlorobiphenyl (4 CB) by a two-membered bacterial culture. Applied microbiology and biotechnology, 21 (3), 192195.

[6] Safe, S. 1993. Toxicology, structure-function relationship, and human and environmental health impacts of polychlorinated biphenyls: progress and problems. Environmental health perspectives, 100, 259

[7] Borja, J., Taleon, D. M., Auresenia, J., and Gallardo, S. 2005. Polychlorinated biphenyls and their biodegradation. Process biochemistry, 40 (6), 1999-2013.

[8] Demirel, B., and Yenigün, 0. 2002. Two-phase anaerobic digestion processes: a review. Journal of Chemical Technology and Biotechnology, 77 (7), 743-755.

[9] Aziz, H. A. (Ed.). 2015. Control and Treatment of Landfill Leachate for Sanitary Waste Disposal. IGI Global.

[10] Furukawa, K., and Fujihara, H. 2008. Microbial degradation of polychlorinated biphenyls: biochemical and molecular features. Journal of bioscience and bioengineering, 105 (5), 433-449.

[11] ATSDR. 2000. Toxicological Profile: Polychlorinated Biphenyls (PCBs). Retrieved from
[12] Martínez, P., Agulló, L., Hernández, M., and Seeger, M. 2007. Chlorobenzoate inhibits growth and induces stress proteins in the PCBdegrading bacterium Burkholderia xenovorans LB400. Archives of microbiology, 188(3), 289-297.

[13] Parnell, J. J., Denef, V. J., Park, J., Tsoi, T., and Tiedje, J. M. 2010 Environmentally relevant parameters affecting PCB degradation: carbon source-and growth phase-mitigated effects of the expression of the biphenyl pathway and associated genes in Burkholderia xenovorans LB400. Biodegradation, 21(1), 147-156.

[14] Mohn, W. W., Westerberg, K., Cullen, W. R., and Reimer, K. J. 1997. Aerobic biodegradation of biphenyl and polychlorinated biphenyls by Arctic soil microorganisms. Applied and environmental microbiology, 63 (9), 3378-3384.

[15] Huang, L. N., Zhou, H., Zhu, S., and Qu, L. H. 2004. Phylogenetic diversity of bacteria in the leachate of a full-scale recirculating landfill. FEMS Microbiology Ecology, 50 (3), 175-183.

[16] Leigh, M. B., Prouzová, P., Macková, M., Macek, T., Nagle, D. P., and Fletcher, J. S. 2006. Polychlorinated biphenyl (PCB)-degrading bacteria associated with trees in a PCB-contaminated site. Applied and Environmental Microbiology, 72 (4), 2331-2342.

[17] Kjeldsen, P., Barlaz, M. A., Rooker, A. P., Baun, A., Ledin, A., and Christensen, T. H. 2002. Present and long-term composition of MSW landfill leachate: a review. Critical reviews in environmental science and technology, 32 (4), 297-336. https://www.atsdr.cdc.gov/toxprofiles/tp.asp?id=142\&tid=26 